The chrysalis (fig. 6) is of a dark shining mahogany color, roughened especially on the anterior edge of the segments in the back. It remains

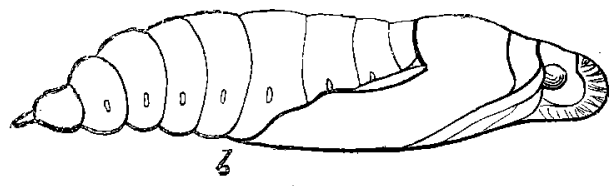

Fig. 6 .

in the ground through the fall, winter and spring months, producing the moth the following summer.

\title{
VARIATIONS IN THE WING EXPANSE OF PEZOTETTIX.
}

BY G. M. DODGE, GLENCOE, NEBRASKA.

In the Can. Ent, vol, ix., p. I I 2 , I have described as a new species, under the name of Caloptenus volucris, a long-winged variety of Pezotettix autumnalis Dodge. I separated it because of its great length of wing, in which respect it equals many specimens of Cal. spretus, while in the typical autumnalis the elytra are very short, ovate and pointed. It also exhibited some variations in color. The latter I have since seen paralleled in autumnalis, and having found long-winged varieties of two other species of Pezotettix, I am now fully satisfied of the varietal character of volucris.

All the authorities agree in making the lack of wings, or the abbreviated character of those organs, the principal reason for separating the genus Pezotettix from Caloptenus. My experience shows, however, that the length of wing in these insects cannot be relied upon as a specific distinction even. It is plain that these long-winged varieties by in-breeding might establish a local variety of what would appear to be Caloptenus, but which would in reality be Pezotettix. It is possible, then, that all our species of Caloptenus were originally Pezotettix; that, by acquiring additional means of locomotion, were enabled to survive their ignoble relatives. This would certainly accord with the natural law of the "survival of the fittest." 
One of my species, Pezotettix alba Dodge, seems to exhibit a transition from something still lower. I have an example in which the elytra are barely one-tenth of an inch in length, only half as long as in the typical or common form. In this specimen the cerci are much smaller than usual, although the insect is of the common size.

I do not yet know whether these variations in wing expanse are common to both sexes or not. I have so far found them only in male specimens, but that is no proof that winged females do not also occur.

Lest any should imagine that I am wrong in determining these longwinged specimens to be varieties rather than species, I will say that these species of Pezotettix are not liable to be confounded with any Caloptenus and that the varieties do not, with the exceptions already mentioned, differ in form or color from the types.

Pezotettix alba is particularly distinct, being white or greenish-white in color, and occurring only upon a native plant whose stems and foliage are also white. This plant, commonly, but incorrectly, called wild sage, grows in clumps many rods apart tpon the prairie; but the insect is never found upon the intervening grass. The winged variety was also found upon the same plant.

The following shows the comparative length of wing in these varieties :-

$$
\text { Pers. alba Dodge. }
$$

Variety, of-Length of elytra, . 10 inch.

Type, $\hat{\delta}$ - Length of elytra, .175 inch.

'Type, $q$ - Length of elytra, .20 inch.

Variety-Length of elytra, .50 or .60 inch.

$$
\text { Pez. junius Dodge. }
$$

Type, $\delta$-Length of elytra, .40 to .45 inch.

Type, $q$--Length of elytra, .45 to .50 inch.

Variety, $\delta$-Length of elytra, .70 inch.

$$
\begin{aligned}
& \text { Pez. autumnatis Dodge. } \\
& \text { Type, } \hat{\delta} \text {-Length of elytra, .20 to } .23 \text { inch. } \\
& \begin{array}{cccc}
\text { " } 9 & \text { " } & \text { " } & .26 \text { inch. } \\
\text { Variety } & \text { " } & & .70 \text { " }
\end{array}
\end{aligned}
$$

The Caloptenoids are not more constant in color than other genera of Acrididæ, red-legged ones producing blue-legged varieties, and vice- 
versa. Worthy of special mention are two males and a female, of the red-legged $C$. spretus, with hind tibia pale blue. As I found them all in one locality, they were probably produced from one batch of eggs. $C$. minor Scudd. has a red-legged variety here. Have taken many specimens, but all were females.

\section{DESCRIPTION OF THE PREPARATORY STAGES OF NEONYMPHA EURYTRIS.}

BY W. H. EDWARDS, COALBURGH, W. VA.

EGG-Sub-globose, well rounded in every part, but somewhat broadest below the middle; wholly covered by fine, irregularly hexagonal reticulations, scarcely raised above the surface; color yellow-green. Duration of this stage 8 days.

YOUNG LARVA-Length .08 inch; cylindrical, thickest in middle, tapering pretty evenly either way, the last segment ending in two short tails ; body covered with fine white hairs, slightly recurved; color pinkwhite, marked longitudinally by seven crimson lines, one of which is medio-dorsal, and three on either side; head sub-globose, nearly twice as broad as any body segment, flattened frontally, depressed slightly at top, and with a small conical process upon each vertex; color dark brown. To next stage 7 days.

AFTER FIRST MOULT--Length . 6 inch. Body flat at base, rounded dorsally, and arched in middle segments, the sides sloping; the tails short, conical : color drab, either of a green or red tint, individuals varying; striped longitudinally with dull red, there being a narrow mediodorsal stripe of this color, and two others on middle of each side; the whole surface finely but roughiy tuberculated, the tubercles being irregular in size and length, sharp, and each emitting a short hair ; colored also according to the ground they occupy; head sub-pyriform, flattened frontally, truncated at summit, and on each vertex a small rounded red process ; color of head yellowish, finely mottled with red. Duration of this stage 6 days. 